\title{
Maritime Piracy and China's Policy Options in Southeast Asian Waters
}

\author{
CHEN Kai * \\ (Assistant Professor at Xiamen University, China)
}

\begin{abstract}
Southeast Asia remains one of the worst-hit regions in maritime piracy; pirates adopt new tactics and anti-piracy security governance presents inefficiencies, particularly sovereignty sensitivity in Southeast Asian waters. This article explores the context-sensitive policy options in the foreseeable future. It' noteworthy that private security companies could be an alternative solution to maritime piracy for China, and the most critical variable would be the China National Security Council.
\end{abstract}

Historically, Southeast Asian waters had acquired a reputation for being a piracy hotspot. The last two decades have seen growing importance placed on Southeast Asian waters, in which security governance of maritime piracy is facing more uncertainties than ever. How to evaluate the dynamics of maritime piracy in Southeast Asian waters? What role do private security companies play in security governance of maritime piracy? How will China respond to maritime piracy in Southeast Asian waters? The answers to these questions are critically needed. In this paper I would like to examine the new tactics adopted by pirates, the issues of sovereignty sensitivity and its consequence (i.e., rise of private security companies) and three would-be scenarios facing China's policy option in the coming future.

\section{New Tactics of Pirates in Southeast Asian Waters}

Since 2005, the joint anti-piracy patrols sponsored by the littoral states (i.e., Singapore, Malaysia and Indonesia) in the Straits of Malacca and Singapore have suppressed maritime piracy to some extent. However, the pirates did not suffer substantial losses in the anti-piracy patrols. A possible explanation is that no empirical evidence is yet available to confirm if any of the supply chains or trafficking routines of pirates have been detected and cut.

In the case of Chinese-flagged vessels attacked by pirates in Southeast Asian waters, it is evident that some pirates have developed more complex tactics. First, the high-risk piracy areas have shifted. According to the reports issued by the Information Sharing Centre of ReCAAP (Regional Cooperation Agreement on Combating Piracy and Armed Robbery), the high-risk piracy areas have shifted from the Straits of Malacca and Singapore to the waters of Indonesia and the South China Sea. This shift has led to an increase in the number of piracy cases reported in the South China Sea. Among the actual incidents reported in 2013, 60\% were more severe incidents. For example, in the South China Sea, six pirates armed with long knives boarded Chineseflagged bulk carrier "CSK Brilliance". They assaulted and tied two duty crew, and stole their personal belongings. On 1 January 2013, two pirates boarded a Chineseflagged bulk carrier "Hua Heng 167" through the anchor chains. The duty crew spotted the pirates and raised the alarm. The pirates jumped into the sea and escaped 
in a speedboat. On 3 June 2013, pirates in a small boat attempted to board Chineseflagged chemical tanker "Atlantic Canyon" via the anchor chain. The duty crew spotted the pirates and raised the alarm. Upon realising that the crew had been alerted, the pirates aborted the attempt. On 24 February 2014, while at anchor, 10 pirates armed with knives boarded Chinese-flagged chemical tanker "Alpine Mia" via the poop deck from an unlit boat. The pirates escaped with a messenger rope and floating buoy. The latest case is Chinese-flagged bulk carrier "Amber Beverly", which was perpetrated by two pirates on 21 February, 2015.

Second, pirates have been using decoy tactics to protect their supply chains or trafficking routines, and distract the attention of anti-piracy forces. The pirates of Southeast Asia are highly organised. Since most Southeast Asian pirates' bases are located in uncharted islands or bays, their supplies highly depend on sea transportation. Therefore, they launch diversionary attacks on passing vessels in order to tire out anti-piracy forces and to protect their secret routines. In reality, pirates are opportunistic and no specific type of vessel is targeted. The decoy tactics did prove effective and led to the wrong conclusion that pirates have become petty theft. As the Annual Report 2014 issued by the Information Sharing Centre of ReCAAP, of the 168 actual incidents reported in 2014,81 were petty thefts, which accounts for $62 \%$ of the total number of incidents. In most cases, searches were conducted onboard the vessels, but no pirates were found. In addition, some pirates could even capitalise on the weak points of the existing vessel-tracking systems.

Third, though there is an increasing concern about the possible link between piracy and terrorism cells in Southeast Asian waters. For instance, as Inquirer (a leading newspaper in the Philippines) reveals in May 2014, four Chinese and German may be the latest hostages of the Abu Sayyaf. More important, some pirates "do not have to cooperate with terrorists to achieve this affect; they can help them inadvertently by simply going about their normal business." According to Martin N. Murphy, the pirates "can nonetheless assist terrorists by sustaining a milieu that deflects intelligence and law enforcement attention away from terrorist activity". ${ }^{1}$

\section{Sovereignty Sensitivity: Achilles' Heel}

It is increasingly impossible to ignore the impacts of sovereignty sensitivities, which have made security governance more inefficient. In the case of littoral countries (especially Indonesia and Malaysia) along the Straits of Malacca and Singapore, they often prioritise national sovereignty and harbour doubts about the involvement of non-littoral countries in anti-piracy operations. As a result, existing maritime security cooperation, such as bilateral agreements, multilateral agreements or initiatives sponsored by non-littoral states are unlikely to achieve the expected results.

In 2004, Admiral Thomas Fargo, the then commander of US Pacific Command (PACOM), announced a Regional Maritime Security Initiative (RMSI) and intimated that US forces might be deployed in the Straits of Malacca and Singapore in response to the escalating piracy threats in Southeast Asian waters. Undoubtedly, this initiative was rejected by Malaysia and Indonesia. Both countries insisted that their forces were fully capable of governing the Strait. The subsequent trilateral patrol in the Straits of Malacca was launched by littoral countries without the leadership of the external

${ }^{1}$ Small Boats, Weak States, Dirty Money: Piracy and Maritime Terrorism in the Modern World. 408 
powers. Until very recently, littoral countries had been governing maritime piracy within their own territories with barely satisfactory results. For example, anti-piracy forces of Singapore and Malaysia cannot gain access to Indonesian waters, without prior consultation. In the report for February 2015 issued by the Information Sharing Centre of ReCAAP, a total of six incidents were reported in SOMS in February 2015, of which one incident occurred in the Malacca Strait and five incidents in the Singapore Strait.

In the South China Sea, the negative impact of sovereignty sensitivity is more significant. Because Malaysia, Philippines, Brunei, Vietnam, China and Taiwan have jurisdictional and overlapping territorial claims to the South China Sea. According to the Annual Report 2014 issued by the Information Sharing Centre of ReCAAP, there has been a surge in the number of incidents involving ships anchored in the SCS, and 23 incidents reported in this region. The number of incidents involving ships underway in SCS has increased consecutively for 3 years since 2012.

\section{Private Security Companies: An Alternative Solution?}

Sovereignty sensitivity has strengthened the argument for the commissioning of private security companies; many stakeholders (i.e., flag states, ship owners, ship operators and ship masters) are hiring private security contractors to meet the increasing demand for protecting their vessels, cargoes and crew. At present, there are hundreds of thousands of private military and security contractors engaged in conflictaffected areas around the world. Many of China's neighbours (notably Japan, India and Russia) have been becoming more dependent on these security companies. As Economist estimated in April 2012, private security contractors have been patrolling the decks of around $40 \%$ of large vessels in the high-risk area that stretches from the Persian Gulf to the Seychelles in the south and the Maldives in the East.

Recent years saw a number of attempts to validate private security contractors' involvement in anti-piracy operations. In 2011, the International Maritime Organisation (a specialized UN agency responsible for ensuring marine security) approved an interim guidance to stakeholders on the use of private security contractors on board vessels in high-risk areas. The ISO/PAS 28007:2012 (Ships and marine technologyGuidelines for Private Maritime Security Companies [PMSC] providing privately contracted armed security personnel [PCASP] on board ships [and pro forma contract]) standards issued by the International Organisation for Standardisation are the latest and most authoritative attempt to separate qualified from the under-resourced and illequipped security providers. ${ }^{2}$

Spurred by the International Maritime Organisation and International Organisation for Standardisation, some governments of flag states have revised the relevant regulations or laws to allow private security contractors on vessels. For instance, on 20 November 2013, the Japanese government passed a landmark national law-"Special Measures Act for Security of Nipponese Vessels in Pirate Infested Waters",

\footnotetext{
2 International Maritime Organization. 2012. Interim Guidance to Private Maritime Security Companies Providing Privately Contracted Armed Security Personnel on Board vessels in the High Risk Area. http://www.imo.org/OurWork/Security/SecDocs/Documents/Piracy/MSC.1-Circ.1443.pdf, accessed 1 January 2015; Gary Howard. 2013. "At last, an accepted international standard for maritime security". http:/www.seatrade-global.com/news/europe/at-last-an-accepted-global-standard-formaritime-security.html?highlight=YToxOntpOjA7aToyODAwNzt9, accessed 1 January 2015
} 
which permits private security contractors aboard Nipponese flagged vessels, and shoot at the pirate ship in order to protect the lives of crew members, as a last resort. Previously, private security contractors were prevented from doing so on Nipponese flagged vessels.

According to a report of the Human Rights Council on its twenty-seventh session ("Annual report of the Working Group on the use of mercenaries as a means of violating human rights and impeding the exercise of the right of peoples to selfdetermination", A/HRC/27/50), many Asian countries have allowed private security contractors to carry firearms. For example, Singapore's law allows private security contractors to carry certain firearms with a special permit; Sri Lanka has a similar requirement. Malaysia's law makes no mention of the use of firearms by private security contractors, but it indicates that an arms license may be issued to a responsible person designated by the security company. A common detail that is usually missing from the regulations is the type of firearms and other non-lethal weapons that security guards can use. The Philippines allows private security contractors to carry weapons subject to the provision of training to security guards and limitations on the types of weapons carried.

At present, there are two major private security companies conducting antipiracy rounds in Southeast Asian waters, namely, the British-based Inchcape Shipping Services and Singapore-based Glenn Defence Marine Asia, which provide armed escorts to oil and gas floating assets and convoys, as well as ocean-going tugs and barges. At the same time, they were the major contractors of the US Navy. For example, Inchcape Shipping Services had received almost \$300 million in Navy contracts, and Glenn Defence Marine Asia held similar contracts in the Pacific valued at more than $\$ 200$ million. $^{3}$

Could private security companies be an alternative option in the long run? In the global scope, there is still no meaningful legal framework governing private security companies' conduct in anti-piracy operations. For example, though the Montreux Document and the International Maritime Organisation lays out a suggested code of conduct and interim guidance for private security companies, they are not legally binding. People have reasons to believe that the involvement of pirate security companies would cause more negative events if private security contractors or companies are still not accountable in anti-piracy operations in the future.

\section{Whither China?}

Though the involvement of private security companies has produced more uncertainties, one thing is certain: they do offer more policy options to China in the foreseeable future.

There are three different would-be scenarios for China's policy choice. In the first scenario, China does not hire private security contractors to escort Chineseflagged vessels in Southeast Asian waters, while the United States and Japan do. On the one hand, this implies that China will have to make great efforts in protecting its

\footnotetext{
${ }^{3}$ Drew, Christopher and Ivory, Danielle. 2014. "Audit Planned in Fraud Case as Navy Reinstates Shipper". The New York Times, http://www.nytimes.com/2014/02/01/us/navy-contractor.html?_r=0, accessed 1 January 2015; Craig Whitlock. 28 November 2013. "Navy suspends business with another contractor". Washington Post.
} 
Chinese-flagged vessels with the use of for instance non-lethal defence (e.g., CCTV and satellite monitoring) and the establishment of double citadels with high-security door locking system. At the same time, Chinese crew should be equipped with reliable and independent two-way external communications, as well as VHF (very high frequency) communication, which are independent from a ship's power supplies.

Moreover, China will also explore alternative strategic channels to reduce the security threats imposed by piracy on Chinese-flagged vessels (e.g., crude oil tankers) in Southeast Asian waters, which would be the nearest alternatives of the Strait of Malacca. The most significant cases should be its huge amount of investment in China-Myanmar pipeline project and its initiative in building the Kra Isthmus Canal, which is the narrowest part of the Malay Peninsula, located in southern Thailand.

The second scenario is the rise of private security companies and their involvement in anti-piracy operations in Southeast Asian waters as an irreversible situation. In such a case, Chinese private security companies will become active in this region than what they used to be. In contrast with Western private security contractors, Chinese contractors have shown certain characteristics. The most significant advantage is lower pricing of Chinese contractors. For most stakeholders, the cost to hire private security contractors would be offset by savings on budget. For most potential employers, a Chinese private security contractor could charge RMB3,000-6,000 per man/month (\$476 to $\$ 952$ ), and $\$ 190$ to $\$ 381$ a day for a group of 12 Chinese private security contractors. Western private security companies could charge $\$ 45,000$ for a four-man team to escort vessels through a high-risk area. ${ }^{4}$ Chinese private security contractors also enjoy same language and culture advantage with Chinese citizens and commercial companies, which "would greatly ease communication, particularly in an emergency". 5

The Chinese government will have to establish a legal code of conduct in accordance with ISO/PAS 28007:2012 (Ships and marine technology-Guidelines for Private Maritime Security Companies [PMSC] providing privately contracted armed security personnel [PCASP] on board ships [and pro forma contract]), the only published international standards dealing with armed guards on ships. The components of ISO/PAS 28007 include the management of the security system (security risk assessments, clearly defined key management responsibilities, legal and other regulatory requirements, and internal audits of operations); procedural aspects (defining rules of authority, selecting contractor, screening and vetting, licensing of firearms, preventing and managing incidents, organising emergency response, investigating and reporting of incidents, specifying procedures for detainment, identification, interface with crew and familiarisation).

Many of the remaining issues not addressed in the former arrangements are included in ISO/PAS 28007. For instance, in Item 3.11 of this standard, it clearly identifies "firearms", that is, "portable barreled weapon from which projectile(s) can be discharged by an explosion from the confined burning of a propellant and the

\footnotetext{
4 "Laws and Guns". 2012. The Economist. http://www.economist.com/node/21552553, accessed 1 January 2015

5 Andrew Erickson and Gabe Collins. 2012. "Enter China's Security Firms". The Diplomat. http://thediplomat.com/2012/02/enter-chinas-security-firms/, accessed 1 January 2015
} 
associated ammunition, related ancillaries, consumables, spare parts and maintenance equipment used by security personnel at sea".

In the final scenario, China will hire non-armed private security contractors to collect anti-piracy intelligence with priority given to the supply chains and trafficking routines of pirates in Southeast Asian waters. Non-armed private security contractors are not however equivalent to mercenaries. According to 47(2) of The Geneva Conventions relating to the Protection of Victims of International Armed Conflicts (Protocol I, 8 June 1977), a mercenary is any person who:

(a) is specially recruited locally or abroad in order to fight in an armed conflict;

(b) does, in fact, take a direct part in the hostilities;

(c) is motivated to take part in the hostilities essentially for private gain and, in fact, is promised, by or on behalf of a party to the conflict, material compensation substantially in excess of that promised or paid to combatants of similar ranks and functions in the armed forces of that party;

(d) is neither a national of a party to the conflict nor a resident of the territory controlled by a party to the conflict;

(e) is not a member of the armed forces of a party to the conflict; and

(f) has not been sent by a state which is not a party to the conflict on official duty as a member of its armed forces.

Being aware of the recruitment, use, financing and training of armed private security contractors for activities which violate principles of sovereign equality and territorial integrity, the hiring of non-armed private security contractors to collect intelligence is understandable in China's case. It is to avoid being directly involved in the sensitive areas in Southeast Asian waters, especially the South China Sea, and the Straits of Malacca and Singapore.

\section{Unresolved Issues}

The findings of this paper differ from most previous research on Southeast Asian piracy. For instance, some pirate attacks should be regarded as decoy tactics to cover pirates' supply chains or trafficking routines, rather than the real purpose of piracy. Further studies are needed to corroborate or contradict this finding. In addition, it does not exclude the possibility that China's anti-piracy policies may go beyond the three speculated scenarios. The most critical variable is the China National Security Council (CNSC), led by President Xi Jinping, with Premier Li Keqiang and top legislator Zhang Dejiang as deputy chiefs. As the most essential body in charge of national security decision-making in China, CNSC must resolve three urgent issues before addressing maritime piracy in Southeast Asian waters, which are underresearched and under-discussed.

First, how will CNSC make full use of available resources, including existing executive bodies and establish an inter-agency permanent institution to integrate them? Second, how will CNSC promote a consensus on future national security legislation 
(e.g., anti-piracy) among China's leaders and policy elites? For example, should China establish a macro framework of national security legislation, or legislate on relevant laws one at a time? Third, though partnerships with both public and private entities would become necessary, not all partnerships will be embraced by the CNSC. Is public-private partnership available for security governance of maritime piracy? These questions remain unanswered. 